\title{
Административная юстиция
}

\section{凡目 и.в. Панова}

профессор, департамент публичного права Национального исследовательского университета «Высшая школа экономики», доктор юридических наук. Адрес: 101000, Российская Федерация, Москва, ул. Мясницкая, 20. E-mail: ipanova@hse.ru

\section{眺 Аннотация}

На основе анализа особенностей развития и современного состояния законодательства, судебной практики рассматриваются актуальные вопросы административной и судебной реформы, раскрывается ряд важных для понимания вопроса терминов (в частности, юридический процесс, административный процесс, административная юстиция, административная юрисдикция, административное судопроизводство), затрагиваются различные проблемы рассмотрения административных дел как в судах, так и в досудебном (внесудебном) порядке. Особое внимание уделено новому Кодексу административного судопроизводства и его согласованности с другими процессуальными законами. Поднимается проблема подведомственности административных дел нескольким коллегиям Верховного Суда, которая приводит к различным результатам рассмотрения аналогичных споров. Критически оцениваются общеюрисдикционный подход суда к рассмотрению споров об административных правонарушениях, связанных с предпринимательской деятельностью. Также выявляются недостатки в осуществлении нормоконтроля по административным делам экономической коллегией Верховного Суда. Большое внимание уделено и проблеме досудебного возмещения убытков, причиненных незаконными действиями административных органов. Предлагается ряд законодательных новелл, касающихся введения порядка досудебного возмещения убытков и ужесточения процедур и мер такой ответственности для субъектов административной власти. В целях обеспечения эффективности института общей административной жалобы и административной защиты прав граждан рассматривается возможность создания в системе исполнительной власти России специального централизованного административного органа по вневедомственному рассмотрению административных дел, способного не только деполитизировать и дебюрократизировать административную власть, но и избавить суды от не свойственной правосудию карательной функции, в частности, привлечения к ответственности по бесспорно мелким административным делам. Доказывается необходимость создания особого административного органа по рассмотрению административных дел, который, во-первых, позволит эффективно (объективно, бесплатно, оперативно) защитить права и законные интересы невластного субъекта; во-вторых, повысит авторитет публичных органов исполнительной власти; в-третьих, разгрузит суды, освободит от несвойственной им функции и не допустит нарушения принципа разделения ветвей власти.

\section{뇨멸 ключевые слова}

административная реформа, административное судопроизводство, административная юрисдикция, административный процесс, административные дела, Кодекс административного судопроизводства, возмещение убытков. 
Для цитирования: Панова И.В. Административная юстиция // Право. Журнал Высшей школы экономики. 2020. № 2. С. 211-229.

Удк: 342

DOI: 10.17323/2072-8166.2020.2.211.229

\section{Введение}

В нашей стране идут административная и судебная реформы. В условиях формирования российской государственности институт административного судопроизводства представляет весьма значительный интерес. Несомненно, в последние годы в России к данной проблеме (как к институту правового государства, в основе которого лежит идея правовой защиты невластных субъектов - гражданина, индивидуального предпринимателя, предприятия) в его отношениях с публичной властью внимание усилилось.

Актуальность теоретико-правового исследования вопросов административно-процессуальной деятельности обусловлена многими факторами, например: 1) идет увеличение рассмотрения административных дел как административно-юрисдикционными органами, так и судьями арбитражной системы и судов общей юрисдикции; 2) институт административной юстиции остается в России на законодательном уровне не установленным, а в теории весьма дискуссионным; 3) принят новый Кодекс административного судопроизводства Российской Федерации от 08.03.2015 N 21-Ф3 (далее КАС); 4) подготовлен проект общей части нового Кодекса об административных правонарушениях ${ }^{1}$.

Один из актуальных вопросов - повышение эффективности российского судопроизводства за счет унификации гражданского процессуального, арбитражного процессуального и административного процессуального законодательства.

\section{1. Понятийный аппарат}

Для начала целесообразно определиться с терминами. Юридический процесс - разновидность социального процесса, который является нормативно установленной формой упорядочивания юридической деятельности (действий) и правовых документов (актов), включающих в себя судебные процессы (судопроизводства) и правовые процедуры Административный процесс - вид юридического процесса, обладающий всеми признаками, присущими последнему (властный характер деятельности; ее регламентация процессуальными нормами; деятельность целевая, сознательная, направ-

\footnotetext{
${ }^{1}$ Available at: URL: https://sozd.duma.gov.ru/bill/703192-6 (дата обращения: 20.04.2020)
} 
ленная на достижение определенных юридических результатов и оформленная в документах). Административный процесс - часть управленческой (исполнительно-распорядительной) деятельности, подлежащей правовой регламентации.

Считаем, что административный процесс публичных органов исполнительной власти состоит из трех частей:

1) административно-нормотворческая часть регламентирует нормотворческие производства по созданию (изменению, приостановлению, отмене) подзаконных нормативных актов исполнительных органов публичной власти в целях создания правовой базы для реализации законов;

2) административно-правонаделительная часть включает производства, регламентирующие правоприменительную, неюрисдикционную деятельность широкого круга исполнительных органов публичной власти по реализации прав и обязанностей индивидуальных и коллективных субъектов в сфере управления, осуществляемую в административно-процессуальной форме;

3) административно-юрисдикционная часть состоит из правоприменительных производств юрисдикционного, принудительного характера широкого круга субъектов исполнительных органов публичной власти по разрешению споров, реализации санкций и защите охранительного правоотношения с применением мер государственного принуждения (административного, дисциплинарного), осуществляемых в административно-процессуальной форме.

Административно-процессуальная деятельность - вид юридического процесса, обладающий всеми признаками, присущими последнему (властный характер деятельности; регламентация деятельности юридическими процессуальными нормами; деятельность целевая, сознательная, направленная на достижение определенных юридических результатов и оформляемая в документах). В настоящее время в российском законодательстве понятия «административная юстиция» и «административное судопроизводство» не совпадают [Бахрах Д.Н., 2009: 2-6]; [Бахрах Д.Н., 2005: 19-25]; [Бурков А.Л., 2003: 62-68]. Термин «административная юстиция» в России на законодательном уровне не установлен и употребляется юристами только в теории.

Административная юстиция включает рассмотрение административных споров в особом (административном) порядке как судебными, так и внесудебными (квазисудебными) административно-юрисдикционными органами.

Административная юрисдикция - установленная законом совокупность правомочий судов, иных государственных органов, органов местного самоуправления и их должностных лиц по рассмотрению административно-правовых дел и исполнению принятых при рассмотрении дел решений. 
Административное судопроизводство - не деятельность администрации, а вид судопроизводства по рассмотрению административных дел в особом порядке, регламентированном нормами административно-процессуального права. Отметим, что административное судопроизводство в арбитражных судах существует. Это свое судоустройство, специализация судей и особый процесс.

Для рассмотрения административных дел ранее предлагалось четыре варианта реформирования: 1) создание самостоятельных административных судов; 2) одновременное функционирование административных судов в рамках существующей судебной системы (как в судах общей юрисдикции, так и в арбитражных судах); 3) принятие единого федерального конституционного закона, регулирующего процедуру рассмотрения дел, возникающих из административных правоотношений, как в судах общей юрисдикции, так и в арбитражных судах; 4) реформирование (усовершенствование) административного судопроизводства в рамках существующих судебных систем путем внесения соответствующих изменений в Арбитражный процессуальный кодекс Российской Федерации от 24.07.2002 N 95-ФЗ (далее - АПК) и Гражданский процессуальный кодекс Российской Федерации от 14.11.2002 N 138-Ф3 (далее - ГПК).

Новый КАС ${ }^{2}$ вступил в силу 15.09.2015. КАС по аналогии с ГПК регламентирует всю процедуру рассмотрения административных дел в судах, начиная от подачи административного искового заявления и заканчивая исполнением судебных актов. Новый кодекс никак не затрагивает и не регулирует вопросов производства по делам об административных правонарушениях (ни в судах, ни в досудебном (внесудебном) порядке), данный порядок остался прежним. КАС также не регулирует вопросов внесудебного производства по административным делам. Его сфера регулирования охватывает только вопросы судопроизводства в судах общей юрисдикции. Арбитражное судопроизводство кодекс также не регулирует. Арбитражные суды будут рассматривать соответствующие административные дела в прежнем порядке.

В то же время некоторые нормы кодекса заимствованы из АПК, например, правила освобождения от доказывания обстоятельств, признанных сторонами ${ }^{3}$ или положение, согласно которому можно приложить к административному исковому заявлению документы в электронной форме 4 . Внедрение подобных норм позволит сблизить порядок рассмотрения админи-

\footnotetext{
2 Кроме части 2 и 4 статьи 45, часть 8 статьи 125, часть 2 статьи 126, часть 7 статьи 299, часть 3 статьи 319, часть 4 статьи 347, части 4, 5 и 9 статьи 353 КАС РФ, которые были введены в действие с 15.09.2016, а пункт 14 статьи 21 КАС РФ - 01.01.2017.

3 СТ. 65 КАС РФ.

4 Ч. 8 ст. 125 КАС РФ.
} 
стративных дел в судах общей юрисдикции с порядком рассмотрения таких дел в арбитражных судах. Подавляющее большинство норм кодекса аналогичны соответствующим нормам ГПК. Таким образом, процедура рассмотрения административных дел осталась в основном неизменной.

Административные дела, рассматриваемые по новому кодексу, следующие ${ }^{5}$ :

1) об оспаривании нормативных правовых актов полностью или в части об оспаривании актов, содержащих разъяснения законодательства и обладающих нормативными свойствами ${ }^{6}$;

2) об оспаривании решений, действий (бездействия) органов государственной власти, иных государственных органов, органов военного управления, органов местного самоуправления, должностных лиц, государственных и муниципальных служащих;

3) об оспаривании решений, действий (бездействия) некоммерческих организаций, наделенных отдельными государственными или иными публичными полномочиями, в том числе саморегулируемых организаций;

4) об оспаривании решений, действий (бездействия) квалификационных коллегий судей;

5) об оспаривании решений, действий (бездействия) Высшей экзаменационной комиссии по приему квалификационного экзамена на должность судьи и экзаменационных комиссий субъектов федерации по приему квалификационного экзамена на должность судьи (далее - экзаменационные комиссии);

6) о защите избирательных прав и права на участие в референдуме граждан Российской Федерации;

7) о присуждении компенсации за нарушение права на судопроизводство в разумный срок по делам, рассматриваемым судами общей юрисдикции, или права на исполнение судебного акта суда общей юрисдикции в разумный срок ${ }^{7}$.

Суды общей юрисдикции согласно КАС также рассматривают и разрешают подведомственные им административные дела, связанные с осуществлением обязательного судебного контроля за соблюдением прав и свобод человека и гражданина, прав организаций при реализации отдельных административных властных требований к физическим лицам и организациям, в том числе административные дела:

\footnotetext{
5 Ч. 2 ст. 1 КАС РФ.
}

${ }^{6}$ Введен Федеральным законом от 15.02.2016 N 18-Ф3 «О внесении изменений в Арбитражный процессуальный кодекс Российской Федерации и Кодекс административного судопроизводства Российской Федерации в части установления порядка судебного рассмотрения дел об оспаривании отдельных актов» // СПС КонсультантПлюс.

7 Ранее такие дела рассматривались в порядке искового производства по гл. 22.1 ГПК. 
1) о приостановлении деятельности или ликвидации политической партии, ее регионального отделения или иного структурного подразделения, другого общественного объединения, религиозной и иной некоммерческой организации, а также о запрете деятельности общественного объединения или религиозной организации, не являющихся юридическими лицами, об исключении сведений о некоммерческой организации из государственного реестра;

2) о прекращении деятельности средств массовой информации; об ограничении доступа к аудиовизуальному сервисув;

3) о взыскании денежных сумм в счет уплаты установленных законом обязательных платежей и санкций с физических лиц;

4) дела, предусмотренные главой 28 КАС (депортация и реадмиссия);

5) об установлении, о продлении, досрочном прекращении административного надзора, а также о частичной отмене или дополнении ранее установленных поднадзорному лицу административных ограничений (далее - административные дела об административном надзоре за лицами, освобожденными из мест лишения свободы);

6) о госпитализации гражданина в медицинскую организацию, оказывающую психиатрическую помощь в стационарных условиях, в недобровольном порядке, о продлении срока госпитализации гражданина в недобровольном порядке или о психиатрическом освидетельствовании гражданина в недобровольном порядке;

7) о госпитализации гражданина в медицинскую противотуберкулезную организацию в недобровольном порядке;

8) иные административные дела о госпитализации гражданина в медицинскую организацию непсихиатрического профиля в недобровольном порядке.

Положения КАС не распространяются на производство по делам об административных правонарушениях, а также по делам об обращении взыскания на средства бюджетов бюджетной системы России. Это связано с тем, что в делах о наложении административных взысканий и их обжаловании реализуется уголовно-правовой тип охранительных отношений (по мнению некоторых правоведов). Поэтому законодатель не соединил в рамках одного процесса деятельность суда по рассмотрению дел о наложении административных взысканий по КоАП и, к примеру, дел по оспариванию действий, актов, решений государственных органов и должностных лиц, где различия типов охранительных правоотношений требуют принципиально

${ }^{8}$ Введен Федеральным законом от 01.05.2017 N 87-Ф3 «О внесении изменений в Федеральный закон «Об информации, информационных технологиях и о защите информации» и отдельные законодательные акты Российской Федерации» // СПС КонсультантПлюс. 
по-разному построенных процессов [Волчецкая Т.С. и др., 2003: 93-101]; [Едидин Б.А., 2004: 17-21].

КАС построен на основе правосудных и «управленческих» (охранительных) функций суда с возможностью рассмотрения им не только споров, но и требующих судебного участия бесспорных вопросов. Это будет широкая административная юстиция. Произошла дифференциация административного судопроизводства на исковое (спорное) и особое (бесспорное) с разработкой единого раздела с общими правилами для всех видов; подразделов с общими правилами для искового и особого производств; отдельных положений с особенностями рассмотрения каждой категории дел внутри искового и особого производств. При таком подходе особое производство в административном судопроизводстве будет составлять достаточно весомую часть кодекса, так как большинство сегодняшних дел особого производства в гражданском процессе с материально-правовой точки зрения включают в себя «административный элемент».

Помимо заимствований норм из АПК и ГПК в КАС содержатся положения, которые предлагается установить впервые. Например, для инициирования судебного разбирательства по правилам КАС необходимо будет обращаться в суд с административным исковым заявлением (в настоящее время в процессуальном законодательстве существуют лишь такие институты, как «исковое заявление» и «заявление»). Также впервые на законодательном уровне будет закреплена норма, позволяющая направлять лицу, участвующему в деле, судебные извещения и вызовы посредством СМС-сообщений либо по электронной почте, если у суда имеется расписка от такого лица с указанием телефона или адреса электронной почты ${ }^{9}$.

\section{2. Административное судопроизводство}

Практика показывает, что в административном судопроизводстве (в рамках действующих нормативных правовых актов и с учетом вступившего в силу КАС) в судах существует достаточное количество дискуссионных вопросов, требующих скорейшего разрешения [Панов А.Б., 2013. С. 24-25]. Например, это следующие вопросы.

1) Подведомственность. Подведомственность - необходимая (неотъемлемая) часть компетенции, которая связывает две стороны правоотношений: ту, которая решает, и ту, которая является зависимой. Подведомственность определяет объекты, на которые распространяется власть субъектов, наделенных властными полномочиями.

\footnotetext{
9 Ч. 1 ст. 96 КАС РФ.
} 
В настоящее время содержательная сторона комплекса проблем определения и разграничения подведомственности качественно изменилась и последовательно трансформировалась в основном в проблемы определения и разграничения видовой подведомственности. Отсюда в свою очередь произошли проблемы определения и разграничения подсудности споров и иных юридических дел. После слияния двух высших судов появился ряд новых проблем подведомственности [Гаджиев Г., 2005: 163-167]; [Громошина Н.А., 2013: 47-57]; [Дерновой В.Б., 2005: 2-11].

Первая проблема в деятельности Верховного Суда Российской Федерации (далее - ВС) заключается в том, что административные дела с участием хозяйствующих субъектов (юридических лиц) одновременно рассматривают две коллегии: Экономическая и Административная.

Рассмотрение дел из публичных правоотношений предполагает особый уровень подготовки судей, поскольку такие дела, как правило, находятся на стыке частного и публичного права. Например, исходя из практики ВС, можно выделить дела: спор с казначейством ${ }^{10}$, таможенное дело ${ }^{11}$, антимонопольное дело ${ }^{12}$, спор с органом контроля за оборотом наркотиков $Ф С \mathrm{CH}^{13}$, налоговое дело ${ }^{14}$. При этом субъектный состав везде - юридические лица. Вышеназванные дела рассматривались судьей, Административной коллегии ВС и везде было отказано заявителю. В споре Роспотребнадзора с продуктовым магазином (хозяйствующим субъектом) дело рассматривалось Административной коллегией ${ }^{15}$. В то же время такие же споры рассматриваются и Экономической коллегией - антимонопольные, налоговые, таможенные. Положение, при котором категорию споров рассматривают две коллегии одновременно (т.е. идет дублирование), вызывает вопросы.

Споры об оспаривании нормативных правовых актов в ВС рассматривает Экономическая коллегия, например, спор между РЖД и ФАС ${ }^{16}$. При этом

${ }^{10}$ Определение Верховного Суда № 305-КГ14-482 02.09.2014. Available at: URL: https://kad. arbitr.ru (дата обращения: 20.04.2020)

${ }_{11}$ Определение Верховного сСуда № 310-КГ14-716 02.09.2014. Available at: URL: https://kad. arbitr.ru (дата обращения: 20.04.2020)

12 Определение Верховного Суда № 309-КГ14-541 02.09.2014 Available at: URL: https://kad. arbitr.ru (дата обращения: 20.04.2020)

${ }_{13}$ Определение Верховного Суда № 304-КГ14-271 03.09.2014. Available at: URL: https://kad. arbitr.ru (дата обращения: 20.04.2020)

${ }_{14}$ Определение Верховного Суда № 305-КГ14-991 02.09.2014. Available at: URL: https://kad. arbitr.ru (дата обращения: 20.04.2020)

15 Определение Верховного Суда № 304-КГ14-1680 18.09.2014. Available at: URL: https://kad. arbitr.ru (дата обращения: 20.04.2020)

16 Определение Верховного Суда № 305-КГ14-1681 01.102014 по делу N A40-27664/12120-258. Available at: URL: https://kad.arbitr.ru (дата обращения: 20.04.2020) 
первоначально дело попало в Административную коллегию, но затем (без указания мотивов) было передано в Экономическую.

Таким образом, несмотря на унификацию, которая преследовалась при объединении судов, избежать разнообразия в толковании и применении норм права при рассмотрении административных дел пока не удается.

Проблема вторая. Также до сих пор трудно было ответить на вопрос, какое правонарушение связано с предпринимательской деятельностью. Судьи ВС предложили такой критерий, как объект посягательства, охраняемый той или иной нормой КоАП. В постановлениях Пленума ВС отмечается, что административные составы в области пожарной безопасности, безопасности дорожного движения и т.д. охраняют именно эти отношения.

Оснований полагать, что правонарушение совершено лицом в связи с предпринимательской деятельностью, не имеется, говорится в постановлениях Пленума ВС [Старилов Ю.Н., 2013: 211-276]. По сути этот подход обозначает презумпцию: пока не доказано обратное, надо исходить из того, что правонарушение не связано с бизнесом. Доказать обратное почти невозможно. Ведь ясно, что все, что делает предприниматель, вытекает из его коммерческой деятельности. Если этого факта недостаточно, то дополнительные доводы привести трудно.

Даже споры об административных правонарушениях, пришедшие из арбитражных судов, Административная коллегия ВС рассматривает так, как это принято в отношении споров из судов общей юрисдикции, т.е. по правилам КоАП и без системы состязательного процесса, предусмотренной в АПК. Для этого была подготовлена нормативная база, ускользнувшая от общего внимания при обсуждении изменений в процессуальные законы. АПК гласит, что в ВС судебные акты по делам об административных правонарушениях обжалуются в порядке, предусмотренном КоАП ${ }^{17}$. КоАП позволяет такие дела рассматривать судье единолично, притом по поручению председателя ВС или его заместителя ${ }^{18}$. Получается, что в арбитражном процессе теперь две «вторые кассации»: одна сложная и с тремя судьями, а другая - простая и с одним судьей. С учетом изменения подведомственности с процедурными особенностями КоАП предпринимателям придется сталкиваться все чаще.

Необходимо подчеркнуть, что разграничение подведомственности - непременное и обязательное условие правосудия. Случаи, при которых дела рассматриваются одновременно судами общей юрисдикции и специализированными судами, или двумя коллегиями одного суда - недопустимы. Также плохо, когда заявления не принимаются ни в одном суде. Лица фактически лишаются права на судебную защиту.

\footnotetext{
17 Ч. 5.1 ст. 211 КоАП РФ.

18 Ч. 4.1 ст. 30.13 КоАП РФ.
} 
2)Оспаривание нормативных правовых актов. Отсутствие в действующем законодательстве единого общепризнанного определения понятия «нормативный правовой акт» порождает споры как в юридической науке, так и в судебной практике. К сожалению, в законе нет понятия нормативного правового акта. Отсутствие определения этого понятия отразилось на ситуации, сложившейся в судебной практике по оспариванию нормативных актов, поскольку отказ в судебной защите права основывается на выводе о не нормативности того или иного правового акта.

Разнобой не только нарушает единообразие в правоприменительной деятельности, но и влияет на пределы судебной защиты прав граждан (других невластных субъектов - индивидуальных предпринимателей, предприятий, учреждений, организаций) от незаконных нормативных правовых актов. Необходимо определиться с понятием нормативного правового акта.

Часто встречаются ссылки на постановление Государственной Думы, в котором даются определения нормативного правового акта и правовой нормы: «Нормативный правовой акт - это письменный официальный документ, принятый (изданный) в определенной форме правотворческим органом в пределах его компетенции и направленный на установление, изменение или отмену правовых норм. В свою очередь, под правовой нормой принято понимать общеобязательное государственное предписание постоянного или временного характера, рассчитанное на многократное применение» ${ }^{19}$.

BC под нормативным правовым актом понимает «изданный в установленном порядке акт управомоченного на то органа государственной власти, органа местного само управления или должностного лица, устанавливающий правовые нормы (правила поведения), обязательные для неопределенного круга лиц, рассчитанные на неоднократное применение, действующие независимо от того, возникли или прекратились конкретные правоотношения, предусмотренные актом» ${ }^{20}$. Аналогичное определение нормативного правового акта содержится и в Указе Президента Российской Федерации ${ }^{21}$. В юридической литературе появилась справедливая критика такого признака нормативного акта, как «установление правила поведения» [Бурков А.Л., 2003: 62-68].

Пленум $\mathrm{BC}^{22}$ заменил формулировку «устанавливающий правовые нормы» на «наличие правовых норм» и назвал следующие признаки норма-

${ }_{19}$ Постановление Государственной Думы от 11.11.1996 N 781-II ГД «Об обращении в Конституционный Суд Российской Федерации» // СПС КонсультантПлюс.

20 Постановление Пленума ВС от 25.05.2000 № 19 «О внесении изменений и дополнений в некоторые постановления Пленума Верховного Суда Российской Федерации» // СПС КонсультантПлюс.

21 Указ Президента РФ от 09.03. 2004 № 314 «О системе и структуре федеральных органов исполнительной власти» // СПС КонсультантПлюс.

22 Постановление Пленума ВС от 29.11.2007 № 48 «О практике рассмотрения судами дел об оспаривании нормативных правовых актов полностью или в части» // СПС КонсультантПлюс. 
тивного правового акта: 1) издание в установленном порядке управомоченными субъектами публичной власти (органом государственной власти, органом местного самоуправления или должностным лицом); 2) наличие в нем правовых норм (правил поведения); 3) обязательность для неопределенного круга лиц; 4) рассчитанность на неоднократное применение; 5) направленность на урегулирование общественных отношений либо на изменение или прекращение существующих правоотношений.

Представляется, что нормативный правовой акт - это (1) письменный официальный документ, (2) принятый в определенной форме субъектом правотворчества; (3) направленный на установление, изменение, введение в действие или отмену правовых норм как общеобязательных предписаний постоянного или временного характера; (3) рассчитанный на многократное применение.

Отметим еще практическую проблему, заключающуюся в том, что Экономическая коллегия ВС, рассматривая в порядке нормоконтроля административные дела, не учитывала до 2019 г. имеющуюся по данному вопросу практику ВС (в том числе Пленума ВС).

Важным событием правоприменительной деятельности является появление в КАС термина «акты, содержащие разъяснения законодательства и обладающие нормативными свойствами». Это послужит достойным выходом из ситуации, при которой отдельный законодательный документ о нормативно правовых актах отсутствует.

3) Оспаривание ненормативных правовых актов. Нет в законодательстве и понятия ненормативного правового акта. Исполнительная власть имеет обширные полномочия, которые строятся на трех позициях: деньгах, оружии и административном усмотрении. Административное усмотрение всегда занимало большое место в правоприменительной деятельности органов исполнительной власти, но оно не должно совпадать с судебным усмотрением. В административно-правоприменительной деятельности много актов. Все ли акты администрации подконтрольны суду? Например, промежуточные акты, ряд предписаний, представлений органов исполнительной власти. Прежде всего речь идет о природе актов администрации, в связи с чем необходимо включить в КАС понятие «ненормативный правовой акт».

Практика рассмотрения дел показывает, что многие акты по своей природе имеют смешанный характер, например, проблемы оспаривания актов по утверждению результатов определения кадастровой стоимости. Трудность заключается в определении природы акта, которым утверждены результаты определения кадастровой стоимости ${ }^{23}$ с с одной стороны, этими актами

${ }^{23}$ Ст. 24.17 Федерального закона от 29.07.1998 N 135-Ф3 (ред. от 18.03.2020) «Об оценочной деятельности в Российской Федерации» // СПС КонсультантПлюс. 
должен утверждаться только средний уровень кадастровой стоимости по муниципальному району ${ }^{24}$, с другой стороны - эти акты содержат сведения о стоимости конкретного объекта недвижимости, а также сведения о кадастровой стоимости и удельных показателей кадастровой стоимости ${ }^{25}$. Получается, что акт субъекта федерации об утверждении результатов определения кадастровой стоимости в части утверждения удельных показателей и среднего уровня кадастровой стоимости является нормативным ${ }^{26}$, а в части утверждения кадастровой стоимости конкретных объектов недвижимости - ненормативным, т.е. носит смешанный характер.

Следовательно, оспаривать удельные показатели и средние значения кадастровой стоимости нужно по правилам оспаривания нормативных правовых актов, а оспаривание кадастровой стоимости объектов недвижимости должно осуществляться по правилам об оспаривании ненормативных правовых актов.

Правила гражданского судопроизводства не дают возможности суду указать в резолютивной части решения об оспаривании нормативного правового акта на те действия, которые следует совершить органам публичной власти в целях устранения допущенного нарушения. Это может быть аргументом в пользу изменения официального подхода к природе актов об утверждении кадастровой стоимости и необходимости рассмотрения подобных споров по правилам административного судопроизводства.

Спорным остается и вопрос о правовой природе такого документа, как «представление», вынесенное административным органом, например, «представление о ненадлежащем исполнении бюджета», выносимое Федеральной службой финансово-бюджетного надзора.

Законодатель указал в нормах Бюджетного кодекса Российской Федерации (далее - БК) в качестве функции вышеуказанного надзорного органа контроль за использованием средств федерального бюджета и средств федеральных внебюджетных фондов, включая использование предоставляемых из указанных бюджетов субвенций, межбюджетных субсидий, иных субсидий и бюджетных кредитов. Руководителю Росфиннадзора предоставляется право по результатам ревизии (проверки) направлять в проверенные организации, их вышестоящие органы обязательные для рассмотрения пред-

24 Часть 2 статьи 66 ЗК РФ.

25 Статья 24.17 Федерального закона от 29.07.1998 N 135-Ф3 (ред. от 18.03.2020) «Об оценочной деятельности в Российской Федерации» // СПС КонсультантПлюс.

${ }^{26}$ Пункт 7 «Обзор законодательства и судебной практики Верховного Суда Российской Федерации за первый квартал 2008 года» (утв. Постановлением Президиума Верховного Суда РФ от 28.05.2008; ред. от 10.10.2012) // СПС КонсультантПлюс. 
ставления или обязательные к исполнению предписания по устранению выявленных нарушений ${ }^{27}$.

Представление руководителей Федеральной службы финансово-бюджетного надзора и ее территориальных органов о ненадлежащем исполнении бюджетного процесса отнесено к мерам принуждения за нарушение бюджетного законодательства ${ }^{28}$ - такого мнения придерживаются арбитражные суды некоторых округов. Однако нельзя согласиться с подобной позицией хотя бы потому, что в БК содержится исчерпывающий перечень мер принуждения за нарушения бюджетного законодательства, в числе которых не содержится такой меры, как вынесение представления о ненадлежащем исполнении бюджета [Радченко В., 2004: 2-5].

Кроме того, трудно назвать спорное представление ненормативным актом, поскольку вынесение представления Росфиннадзором по результатам ревизий (за исключением представлений с требованием о возмещении средств) адресовано проверенной организации, и лишь предлагает принять меры по недопущению в дальнейшем совершения указанных нарушений бюджетного законодательства. Спорное представление, в отличие от предписания, обязательно для рассмотрения учреждением.

Данное представление не носит властно-распорядительного характера, а лишь отражает сведения о нецелевом использовании последним средств федерального бюджета, носит информационный и разъяснительный характер и, следовательно, не влечет никаких правовых последствий. Данный документ не является окончательным по решению вопроса, поэтому не может быть самостоятельным предметом спора в арбитражном суде. Кроме того, поскольку обжалуемое представление не содержит каких-либо властных предписаний комитету, оно не нарушает прав и законных интересов поднадзорного органа [Зеленцов А.Б., 2015: 39-46]; [Николаева Л.А., Соловьева А.К., 2004: 111].

Таким образом, ряд вопросов административного судопроизводства нуждается в детальной регламентации, что послужит важнейшей процессуальной гарантией защиты прав граждан.

27 П. 5.14.3. Положения о Федеральной службе финансово-бюджетного надзора, утвержденном Постановлением Правительства Российской Федерации от 15.06.2004 N 278, а также п. 122 Административного регламента исполнения Федеральной службой финансово-бюджетного надзора государственной функции по осуществлению контроля и надзора за соблюдением законодательства Российской Федерации в финансово-бюджетной сфере при использовании средств федерального бюджета, средств государственных внебюджетных фондов, а также материальных ценностей, находящихся в федеральной собственности, утвержденного Приказом Министерства финансов от 04.09. 2007 № 75-н.

28 СТ. 284 БК РФ. 


\section{3. Административная процедура рассмотрения административных дел}

\section{1. Административный порядок возмещения убытков невластным субъектам по административным делам}

Внесудебный порядок возмещения убытков по административным делам оказывает существенную помощь в защите прав потерпевшего, гарантирует возмещение и даже отсутствие убытков, а также позволяет избежать долгого судебного разбирательства и последующего не менее долгого, сложного и порой существенно затратного процесса исполнения судебного решения [Лазаревский Н., 1905: 205]. Данный порядок позволит избежать будущих споров и сформировать четкое понимание уровня и размера ответственности при причинении убытков по административным делам. Это в значительной мере дисциплинирует субъектов административного правоотношения.

В законодательство следует ввести правило, в соответствии с которым нарушать права невластных субъектов со стороны должностных лиц было бы невыгодно. Устранению несовершенства законодательства в сфере обжалования способствовало бы принятие федерального закона «Об общих принципах и порядке реализации права на возмещение вреда государством», регулирующего общие принципы реализации права на возмещение вреда государством. Концепция такого закона может быть разработана на основе правовых позиций высших судов Российской Федерации.

Кроме того, возможно рассмотреть целесообразность введения ранее действовавшего в соответствии с Указом Президиума Верховного Совета $\mathrm{CCCP}^{29}$ порядка предоставления в некоторых строго ограниченных случаях возможности внесудебного порядка возмещения убытков. Например, когда подлежит возмещению только реальный ущерб и имеется вступившее в законную силу судебное решение, подтверждающее факт незаконных действий государственных органов и их должностных лиц.

Возможно ввести внесудебный (административный) порядок взыскания убытков при совершении административного правонарушения или причинении вреда незаконными действиями должностных лиц (органов), установить предельный размер суммы взыскания - 100 тыс. руб., ввести в КоАП статью, согласно которой убытки в порядке меры административно восста-

29 Указ Президиума Верховного Совета СССР от 18.05.1981 «О возмещении ущерба, причиненного гражданину незаконными действиями государственных и общественных организаций, а также должностных лиц при исполнении ими служебных обязанностей» (утв. Законом СССР от 24.06.1981) (вместе с «Положением о порядке возмещения ущерба, причиненного гражданину незаконными действиями органов дознания, предварительного следствия, прокуратуры и суда») // СПС КонсультантПлюс. 
новительной могли быть взысканы одновременно с рассмотрением вопроса об административной ответственности.

Целесообразно дополнить ст. 4.21 КоАП «Досудебное возмещение убытков» положением:

«Если в результате совершения административного правонарушения гражданину, предпринимателю, учреждению или организации был причинен имущественный вред, то потерпевшая сторона имеет право на возмещение убытков в досудебном порядке в случае, если сумма имущественного ущерба не превышает 100 тысяч рублей.

Досудебное рассмотрение производится органом исполнительной власти Российской Федерации - управлением Федеральной антимонопольной службы.

В других случаях вопрос о возмещении имущественного ущерба, причиненного административным правонарушением, решается по общим правилам гражданского судопроизводства с соблюдением соответствующей подсудности».

Досудебное рассмотрение производит управление Федеральной антимонопольной службы. В других случаях вопрос о возмещении имущественного ущерба, причиненного административным правонарушением, решается по общим правилам гражданского судопроизводства с соблюдением соответствующей подсудности». Кроме того, целесообразно дополнить КАС следующим положением: «Граждане вправе подавать в суд заявления о возмещении вреда или убытков, причиненных незаконными действиями административных органов, в случае письменного отказа соблюдения досудебного порядка урегулирования споров со стороны должностного лица».

Также следует дополнить КАС абзацем: «В случаях, установленных законом, при рассмотрении жалобы о возмещении убытков (вреда), причиненного незаконными действиями (бездействием) должностного лица, суду необходимо учитывать обязанность соблюдения досудебного порядка рассмотрения вопроса о возмещении убытков (вреда) в пределах до 100 тыс. руб.». Целесообразно также установить правило, по которому за противоправное поведение должностного лица (которое в административном порядке не возместило убытков) несет ответственность в суде орган или вышестоящее должностное лицо. В соответствии с этим следует дополнить КАС абзацем: «Если должностное лицо, которое по закону обязано возместить убытки в административном порядке, не возместило данные убытки (вред), причиненный незаконными действиями (бездействием) такого лица и (или) уклоняется от явки в суд, то обязанность такого возмещения в порядке подчиненности переходит к вышестоящему должностному лицу».

Также возможно в соответствующих статьях АПК, ГПК и КАС закрепить следующую норму: «Если соответствующий субъект в административном 
порядке добровольно не уплачивает убытки, причиненные незаконными действиями (бездействием) должностных лиц, сумма, взыскиваемая через суд, может быть увеличена».

Иными словами, законодательство должно стимулировать возмещение вреда в административном порядке в противовес большим финансовым затратам в судах.

\section{2. Создание особого административного органа по рассмотрению административных дел}

Реформа административного судопроизводства невозможна без параллельного реформирования административного порядка рассмотрения дел, который бы мог освободить суд: а) от не свойственной ему карательной функции по привлечению к административной ответственности; б) от мелких дел. Потребность в общегосударственном контроле в таком государстве, как Россия с ее обширными территориями, очевидна, так как это: 1) позволит объективно, бесплатно, оперативно защитить права и законные интересы невластного субъекта; 2) повысит авторитет публичных органов исполнительной власти; 3) разгрузит суды, освободит от несвойственной им функции и не допустит нарушения принципа разделения ветвей власти, которое сейчас имеется при рассмотрении ряда административных дел судами.

В России не создавались специальные административно-юрисдикционные органы, которые рассматривали бы общую административную жалобу за рамками ведомственного интереса. Таким органом может стать Федеральная административная служба (Административная палата). Административная палата могла бы выполнять три основные функции при рассмотрении дел, возникающих из административных правоотношений.

Во-первых, это рассмотрение общей административной жалобы.

Во-вторых, это привлечение к административной ответственности физических и юридических лиц по составам дел об административных правонарушениях, указанных в КоАП ${ }^{30}$ и относящихся в настоящее время к подведомственности мировых судей, судов общей юрисдикции и арбитражных судов (административная внесудебная процедура). Обжалование данных постановлений об административном правонарушении будет возможно только в судебном порядке.

B-третьих, это пересмотр постановлений по делам об административных правонарушениях по всем категориям дел независимо от субъектного состава (административная досудебная процедура). При этом в администра-

\footnotetext{
30 СТ. 23.1 КоАП РФ.
} 
тивном законодательстве следует установить процедуру, при которой по определенным категориям дел об административных правонарушениях административная досудебная процедура могла быть обязательной.

\section{Заключение}

Создание подобного органа, входящего в систему органов исполнительной власти, позволит деполитизировать процесс рассмотрения споров, повысить профессионализм и оперативность при рассмотрении дел об административных правонарушениях; способствовать понижению бюрократизма и коррупции в органах исполнительной власти; уменьшить издержки рассмотрения административных дел физических и юридических лиц. Такая реализация законных прав граждан и юридических лиц разгрузит суды, что позволит сэкономить бюджетные средства и повысит качество правосудия, а также не допустит нарушения принципа разделения ветвей власти, которое сейчас имеется при рассмотрении ряда административных дел судами.

При этом административная процедура рассмотрения административных дел не должна повторять судебное рассмотрение, а должна, напротив, быть предельно простой, открытой и что весьма важно - бесплатной для невластных субъектов (граждан и коллективных субъектов).

\section{Б目 Библиография}

Бахрах Д.Н Административно-процессуальная деятельность государственной администрации // Административное право и процесс. 2009. №3. С. 2-6.

Бахрах Д.Н. Административное судопроизводство, административная юстиция и административный процесс // Государство и право. 2005. № 2. С. 19-25.

Бурков А.Л. Квопросу об отраслевой принадлежности института административной юстиции // Журнал российского права. 2003. № 4. С. 62-68.

Волчецкая Т.С. и др. Становление административной юстиции в Российской Федерации и Литовской Республике // Журнал российского права. 2003. № 8. С. 93-101.

Гаджиев Г. Конституционно-правовые ориентиры при создании системы административных судов в Российской Федерации // Сравнительное конституционное обозрение. 2005. № 3. С. 163-167.

Громошина Н.А. Кодекс административного судопроизводства: оценка перспектив // Вестник гражданского процесса. 2013. № 3. С. 47-57.

Дерновой В.Б. Развитие системы административной юстиции в Российской Федерации // Российская юстиция. 2005. № 4. С. 2-11.

Едидин Б.А. Формирование административной юстиции в России: некоторые вопросы теории и практики // Российский судья. 2004. № 11. С. 17-21.

Зеленцов А.Б. Административное судебное право: концептуальные проблемы формирования // Административное право и процесс. 2015. № 2. С. 39-46. 
Зеленцов А.Б. Административно-правовой спор: вопросы теории: Монография. М.: РУДН, 2005. 732 c.

Зеленцов А.Б., Радченко В.И. Административная юстиция в России (история и современность). М.: Рос. акад. правосудия, 2001. 119 с.

Лазаревский Н. Ответственность за убытки, причиненные должностными лицами: Догматическое исследование. СПб.: Слово, 1905. 712 с.

Николаева Л.А., Соловьева А.К. Административная юстиция и административное судопроизводство: зарубежный опыт и российские традиции. СПб.: Юридический центр Пресс, 2004. 332 с.

Панов А.Б. Административная ответственность юридических лиц. М.: Норма, 2013. 192 c.

Радченко В.И. Административные суды призваны защитить человека от произвола недобросовестных чиновников // Российская юстиция. 2004. № 3. С. 2-5.

Старилов Ю.Н. От административной юстиции к административному судопроизводству / Административное судопроизводство в Российской Федерации: развитие теории и формирование административно-процессуального законодательства. Вып. 7. Воронеж: Изд-во Воронежск. гос. ун-та, 2013. С. 211-276.

\section{Pravo. Zhurnal Vysshey Shkoly Ekonomiki. 2020. No 2}

\section{The Administrative Justice}

\section{目 Inna Panova}

Professor, Department of Public Law, National Research University Higher School of Economics, Doctor of Juridical Sciences. Address: 20 Myasnitskaya Str., Moscow 101000, Russian Federation. E-mail: ipanova@hse.ru

\section{唯国 Abstract}

The analysis presented in the article features as to the development of modern legislation, legal practice, contributes to studying the urgent issues of administrative and judicial reforms, shows a number of significant terms in question, in particular legal process as a whole, administrative process, administrative justice), touches upon various issues of judging administrative case judicially or extra judicially. A special attention is drawn to the new Code of administrative procedure of the Russian Federation and its coordination with other procedural laws. The article raises the problem of the jurisdiction of administrative cases to several collegiums of the Supreme Court of the Russian Federation, which leads to various outcomes of similar disputes. The paper assesses critically the general jurisdiction approach of courts to judging the cases associated with entrepreneurship. It reveals the drawbacks in performing the control over norms on administrative cases. A significant attention is given to prejudicial recovery of losses. To ensure the efficiency of the institute of general administrative claim and administrative protection of the rights of citizens, the paper suggests the possibility to create a special centralized body within the system of Russian executive power to judge administrative cases, which would be able to make administrative power less bureaucratized one and to allow courts avoid the execution of punishment. The article proves the necessity to create an additional administrative body that will allow protecting the rights and legal interests of citizens and 
public bodies of executive power and will not allow the breach of the separation of powers principle.

\section{O-1国 Keywords}

administrative reform, administrative procedure, process, administrative cases, Code of administrative procedure, compensation of losses.

For citation: Panova I. V. (2020) The Administrative Justice. Pravo. Zhurnal Vysshey shkoly ekonomiki, no 2, pp. 211-229 (in Russian)

DOI: $10.17323 / 2072-8166.2020 .2 .211 .229$

\section{O-4国 References}

Bakhrakh D.N. (2009) Administrative procedural activity of state administration. Administrativnoe pravo i protsess, no 3, pp. 2-6 (in Russian)

Bakhrakh D.N. (2005) Administrative procedure, administrative justice. Gosudarstvo i pravo, no 2, pp. 19-25 (in Russian)

Burkov A.L. (2003) Re the branch for the institute of administrative justice. Zhurnal rossiyskogo prava, no 4, pp. 62-68 (in Russian)

Dernovoy V.B. (2005) The development of administrative justice in the Russian Federation. Rossiyskaya yustitsiya, no 4, pp. 2-11 (in Russian)

Edidin B.A. (2004) The formation of administrative justice in Russia. Rossiyskiy sud'ya, no 11, pp. 17-21 (in Russian)

Gadzhiev G. (2005) Constitutional and legal framework for a system of administrative courts in the Russian Federation. Sravnitelnoe konstitutsionnoe obozrenie, no 3, pp. 163167 (in Russian)

Gromoshina N.A. (2013) Administrative code: outlook. Vestnik grazhdanskogo protsessa, no 3, pp. 47-57 (in Russian)

Lazarevskiy N. (1905) Liability for the damages caused by officials. Saint Petersburg: Slovo, 712 p. (in Russian)

Nikolaeva L.A., Solovyova A.K. (2004) Administrative justice and administrative procedure abroad and in Russia. Saint Petersburg: Yuridicheskiy tsentr Press, 332 p. (in Russian)

Panov A.B. (2013) Administrative liability of legal persons. Moscow: Norma, 192 p. (in Russian)

Radchenko V. (2004) Administrative courts should protect a person against dishonest officials. Rossiyskaya yustitsiya, no 3, pp. 2-5 (in Russian)

Starilov Yu.N. (2013) From administrative justice towards administrative protsess. Administrativnoe sudoproizvodstvo v Rossii, no 7, pp. 211-276 (in Russian)

Volchetskaya T.S. et al. (2003) The origins of the administrative justice in Russia and Lithuania. Zhurnal rossiyskogo prava, no 8, pp. 93-101 (in Russian)

Zelentsov A.B. (2015) Administrative judicial law: concepts of formation. Administrativnoe pravo i protsess, no 2, pp. 39-46 (in Russian)

Zelentsov A.B. (2005) Administrative law dispute. Moscow: RUDN, 732 p. (in Russian)

Zelentsov A.B., Radchenko V.I. (2001) Administrative justice in Russia. Moscow: RAP Press, 119 p. (in Russian) 